NEWS

\title{
Deadly flu virus can be sent through the mail
}

The reconstructed version of the flu virus that caused the 1918 world pandemic will be mailed to registered labs that ask for it, despite previous assurances to the contrary, Nature has learned.

The DNA sequence of the virus, which killed some 50 million people when it swept the globe in 1918-19, was reported by US researchers last month (J. K. Taubenberger et al. Nature $437,889-893 ; 2005)$. At the same time, another group described how it used that sequence to reconstruct the complete virus for the first time (T. M. Tumpey et al. Science 310,77-80; 2005).

Critics such as virologist Jens Kuhn of Harvard Medical School say that the virus should never have been recreated in the first place, as it could escape and cause another pandemic. Giving the virus to more labs, not to mention sending it in the mail, adds to that risk, they say. Others argue that such studies are safe, and can help to discover what made the virus so deadly. "We have to be careful," says US health secretary Michael Leavitt. "But on the other hand we have to have the ability to study it."

Scientists at the Centers for Disease Control and Prevention (CDC) in Atlanta, Georgia, where the virus is held, initially answered concerns that it might escape by emphasizing that only one person, microbiologist Terrence Tumpey, had access to it (see Nature 437, $794-795$; 2005). Tumpey said that he had undergone extensive background security checks, and had to pass through tough safety procedures every time he entered the lab. The $\mathrm{CDC}$ also said that the virus would not be sent out to any other labs.

The agency now seems to have changed its mind. Spokesman Von Roebuck told Nature last week that labs that are registered to work with select agents - in particular, dangerous pathogens that are subject to specific handling rules - will be able to request the virus. The reconstructed flu virus was added to the CDC's select-agents list on 20 October.

The designation means that labs that operate under enhanced biosafety level-3 conditions or higher will be able to work with the virus. The highest biosafety level is 4 , which requires full body suits. But enhanced level-3 conditions still require lab workers to wear respirators and to shower before leaving the lab. According to the select-agent rule, it is also "strongly recommended" that lab workers are vaccinated with the annual flu vaccine, which may offer partial protection.

No lab has yet formally requested the virus, Roebuck says. But some scientists say they would like to work with it. Michael Katze, a virologist at the University of Washington in Seattle, says there are plans to renovate his institution's primate centre so that his group can at least work with forms of the virus that contain some of the 1918 genes. Katze says he will study the virulence of the 1918 strain by infecting macaques with a mutated version of the virus. At some point, he also wants to work with the fully reconstructed virus, he says.

Scientists in Canada are planning to work with the virus, although they will not request it from the CDC. Constructs containing the virus's DNA will be made at the University of Wisconsin-Madison and will be sent to the National Microbiology Laboratory in Winnipeg, Canada, according to Frank Plummer, the laboratory's scientific director. Reconstructing the live virus from its DNA would then take just a few days, he says.

The researchers at the Winnipeg lab, which has level-4 certification, will infect mice and macaques to identify which parts of the virus make it so virulent. Such knowledge may enable researchers to identify potentially dangerous flu strains and develop vaccines against them. The work has been given extra urgency by the avian flu strains currently being carried by birds migrating from Asia. Researchers analysing the 1918 sequence have
IMAGE UNAVAILABLE FOR COPYRIGHT REASONS

concluded that the virus was one that had jumped to humans from birds.

If it is sent out, the 1918 virus could be shipped by commercial carrier services that allow it to be tracked, says Clarence Peters, a virologist at the University of Texas Medical Branch in Galveston. Frozen samples of select agents are shipped in a plastic vial wrapped in absorbent material that would soak up any

\section{How bad would it be if the virus escaped?}

Nobody really knows what the consequences would be if the reconstructed 1918 virus escaped orwas released maliciously.

Some virologists point out that current flu drugs and vaccines are partially effective in mice against virus strains containing key genes from the 1918 flu. But Clarence Peters, a virologist at the University of Texas Medical Branch in Galveston, says the vaccine has not been tested on the full virus, and points out that flu viruses could quickly mutate to become resistant to drugs given to researchers working with the 1918 strain.

There is little research on how the virus is transmitted between humans or on how long it survives on surfaces, adds Matthew Meselson, a biologist and bioweapons expert at Harvard University.

Andrew Pekosz, a virologist at
Washington University School of Medicine inSt Louis, Missouri, saysstudies from the 1970 s show that itcansurvive on surfaces for several hours. Petersalso points out that if the 1918 fluvirusinfected someone, it would be much harder to contain than, say, Ebola, which requires close contact to pass from one person to another. "It wouldspread quickly, particularly given travel and transporttoday," hesays. A.V.B. 


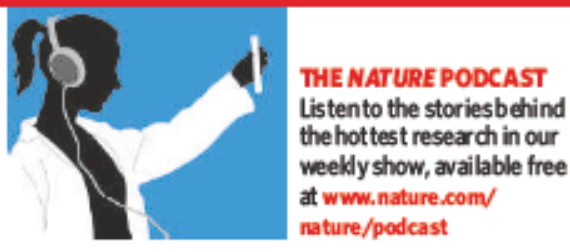

\section{Far East lays plans to be stem-cell hotspot}

Asia is aiming to secure its place as the world leader for cloning technologies. Many of the world's leading stemcell biologists and cloning specialists hail from countries such as South Korea and Jap an. And judging by the second Asian Reproductive Biotechnology conference, held from 2 to 7 November in Bangkok, Thailand, these pioneers are willing to share knowledge and techniques with scientists from less developed neighbours in the region, who are keen to enter the game.

"There is huge potential for Asian scientists here," says Woo Suk Hwang of Seoul National University in South Korea, who last year led the first team toderive stem cells from a cloned humanembryo.

Strong government supportand relatively relaxed ethical regulations are often cited as reasons for Asia's success in stem-cell biology, but Hwang singles out technical prowess as a critical factor. Many stem-cell biologists have noted that some labs in Europe and the
United States have struggled with skills already mastered by researchers in Asia, such as those needed to operate the micromanipulator devices used to remove nuclei from cells during the cloning process.

The researchers at the meeting, who numbered around 150 , saw a demonstration of one such technique from Teruhiko Wakayama of the RIKEN Center for Developmental Biology in Kobe, Japan, who in 1998 created the first cloned mouse. Biologists from Vietnam and Thailand were able to try extracting nuclei from egg cells with his piezoelectric device.

Many labs in Asia, in which even basics such as refrigerators can run short, cannot afford to experiment with such techniques, says Nguyen Van Thuan, who also works at the RIKEN Center. He presented one potential solution: a method for storing mouse sperm at room temperature for up to a week by adding salt to the bovine serum album in solution in

leaks. That vial is placed inside at least one other plastic container. This is held inside a polystyrene box containing dry ice, which itself lies inside a heavy cardboard box. Some of the packaging must pass tests such as freefall drops and has survived air crashes, says Plummer: "It's very, very safe."

Critics note that there is still a risk that the package could be lost or misdelivered, but Plummer says that is unlikely because the sender and recipient would know that the package is in transit. He adds that other select agents, including Ebola virus, are frequently sent in this way. If the virus did escape, it is unclear how serious the consequences would be (see 'How bad would it be if the virus escaped?').

Kuhn argues that the more places and people work with the virus, the greater the chance that it will escape or be stolen. He says that there should be an international agreement that restricts work on the virus to a few laboratories worldwide.

Andreas von Bubnoff

See Editorial, page 130

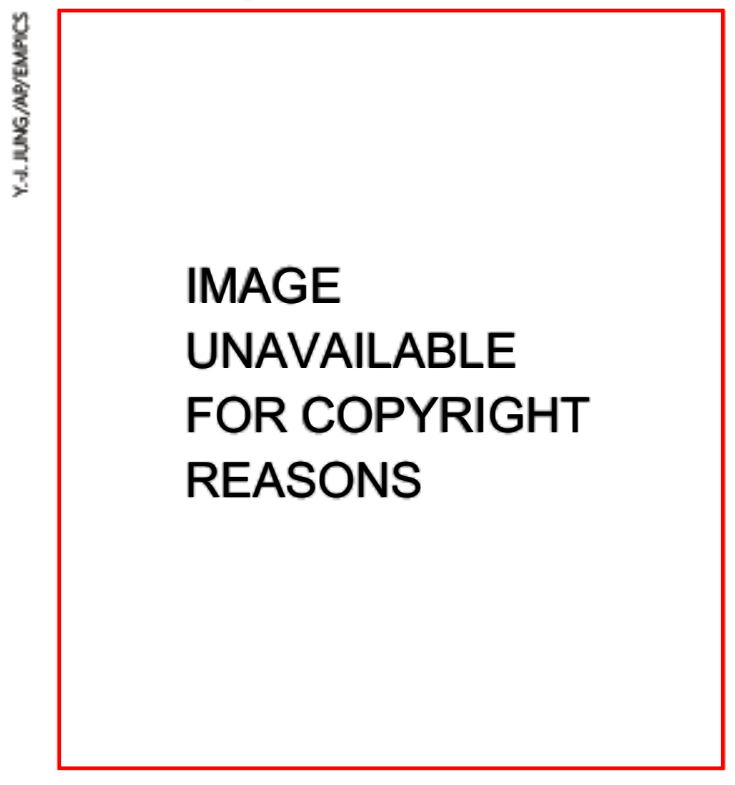

WooSuk Hwang says Asia has huge potential in cloning. which the sperm is often held (N. Van Thuan et al. Biol. Reprod. 72, 444-450; 2005). Thuan, who is Vietnamese, says that the technique could help his country's scientists to transport samples and run studies involving mice sperm, without taking up scarce refrigerator space.

Despite a lack of resources, Thailand and Vietnam host country for the first Asian Reproductive Biotechnology meeting are hoping for a bright future. The Thailand Research Fund willstart a US\$50-million grant programme for stem-cell research in 2006, and earlier this year the Vietnamese government promised to boost research spending to $2 \%$ of its gross domestic product (GDP).

This will more thandouble current investment, and a goodchunk is expected togo to reproductive biology. Two stem-cell scientists, Nguyen Mong Hung at the Hanoi University of Science, and Bui Xuan Nguyen at the Vietnamese Academy of Science and Technology in Hanoi, will be getting US $\$ 500,000$ a year to head centres of excellence in the field.

Hwang says that there is particular scope for collaboration in the cloning and derivation of monkey stem cells todevelop models for hum an disease. He expects that a collaboration of scientists from South Korea, Japan, China and other Asian countries with access to primate populations will form a significantpart of his recently formed network for exchanging stem-cell lines and cloning technology (see Nature 437, 1077; 2005). David Cyranoski 